\title{
Chapter 8
}

\section{Life stories, family relations and the 'lens of migration': postwar British emigration and the new mobility}

\section{A. James Hammerton}

This chapter offers some reflections on the changing ways in which Western - and more particularly British - emigrants have come to describe and reflect on their lives in the second half of the twentieth century. It arises from a current project on late twentieth-century British emigration to multiple locations, which explores ways in which the post-1960s period of heightened mobility and cheaper transport has brought about shifts in migrant identities while retaining some continuities with traditional modes of migration and migrants' own telling of their stories. ${ }^{1}$ It involves scrutiny of ways in which migrants construct their life histories and how that has changed since the period represented in Australia by the 'ten-pound Poms' generation of British migrants from the 1940s to the 1960s, with some particular reference here to marital and family relations. ${ }^{2}$ 'How we emigrate now' has undergone profound changes since about the 1960s, and it is timely to begin to undertake the historical task of tracing how one mode of migration, and the expression of the migrant life and identity, has evolved into a different, more transnational, one in the past four decades - albeit with elements of both continuity and change in practice. Given the enormous exodus of the British in the 30 years after 1945, the sustained and newsworthy level of the British diaspora right down to the present, and still with the great benefit of the colonial dividend - which bequeathed half a world of convenient linguistic migrant destinations - the British make an excellent case study in the evolution of the modern mobility among the populations of the West. ${ }^{3}$ Their migration stories, in which Australia plays a central but not exclusive role, are quintessentially transnational, and underline the value of viewing even the most intimate accounts of migrant biography through a transnational lens.

Several themes emerge from a qualitative study of the life histories of those modern, often serial migrants to a succession of countries, who left Britain in the years after the late 1960s. First, the old self-improvement ethos in family and individual terms, which, arguably, characterises most British emigration 
from the early nineteenth century until the 1960s, has been replaced, gradually, by a different set of attitudes to migration, which define it primarily in terms of adventure, the consumption of transnational experience and a sharp eye for expatriate money-making around the globe. ${ }^{4}$ Second, from about the 1970s, we can see the emergence of a new definition of the migrant self as inherently mobile and transnational, encapsulated in frequent declarations such as 'I'm a citizen of the world', 'I'm international' and 'I don't belong to any one country'. This is closely related to the tendency for migrants to construct the narrative of their lives through a lens of migration, regardless of the power of other events in their lives. It has competed with and often edged aside more traditional constructions of migrant identity around notions of migration as an epic struggle to succeed and an ultimate vindication of the decision to leave and settle permanently in one country. Third, among a substantial minority there is a tendency for modern migrants' marriages to be transnational. Increasingly, the dynamics of global occupations and multicultural societies have facilitated the incidence of multiracial marriages that are themselves likely to be highly mobile. More commonly, British migrants have first met and married transient Australians, Canadians, New Zealanders or Americans in Britain, and then decided to relocate to their spouse's country. While such migrants are quintessentially modern products of a mobile world, the implications for married life, regardless of the gender of the migrant spouse, tend to be very similar to those we associate with the migrant 'war brides' of the 1940s. The more traditional courtship and marriage of a settled migrant to a native-born partner in the new country carries quite different meanings for both spouses compared with the effective 'importation' of a spouse new to the country; in recent decades the wider choices available to newly married but unsettled partners can lead to more volatile marriages. For such reasons, the implications of migration for marriage and family life are particularly important.

These are the kinds of themes that surface when migrants recollect their life stories, whether in written form or into a microphone with an oral historian, and they will recur in some of the narratives that follow. For the autobiographically minded, the transformative potential of migration has often served as an additional spur to record their experiences and reflections of them. Kate Boyle, who came to Melbourne in 1998 from Staffordshire, noted that her fortieth birthday in 2005 seemed 'an appropriate time to consider the journey here'. She sent us this communication before writing a long life history that placed her migration at its centre:

I would love to tell my story and hear others, the whole experience is so life changing that it is hard not to tell others some of the stuff you go through in the process of moving home, country, leaving behind relatives and friends, making new friends, getting to know in-laws, encountering new health and education systems. ${ }^{5}$ 
Figure 8.1: 'Nomads on the Move Again': modern migrants. Since the 1960s migrants have tended to see themselves as inherently mobile and transnational.

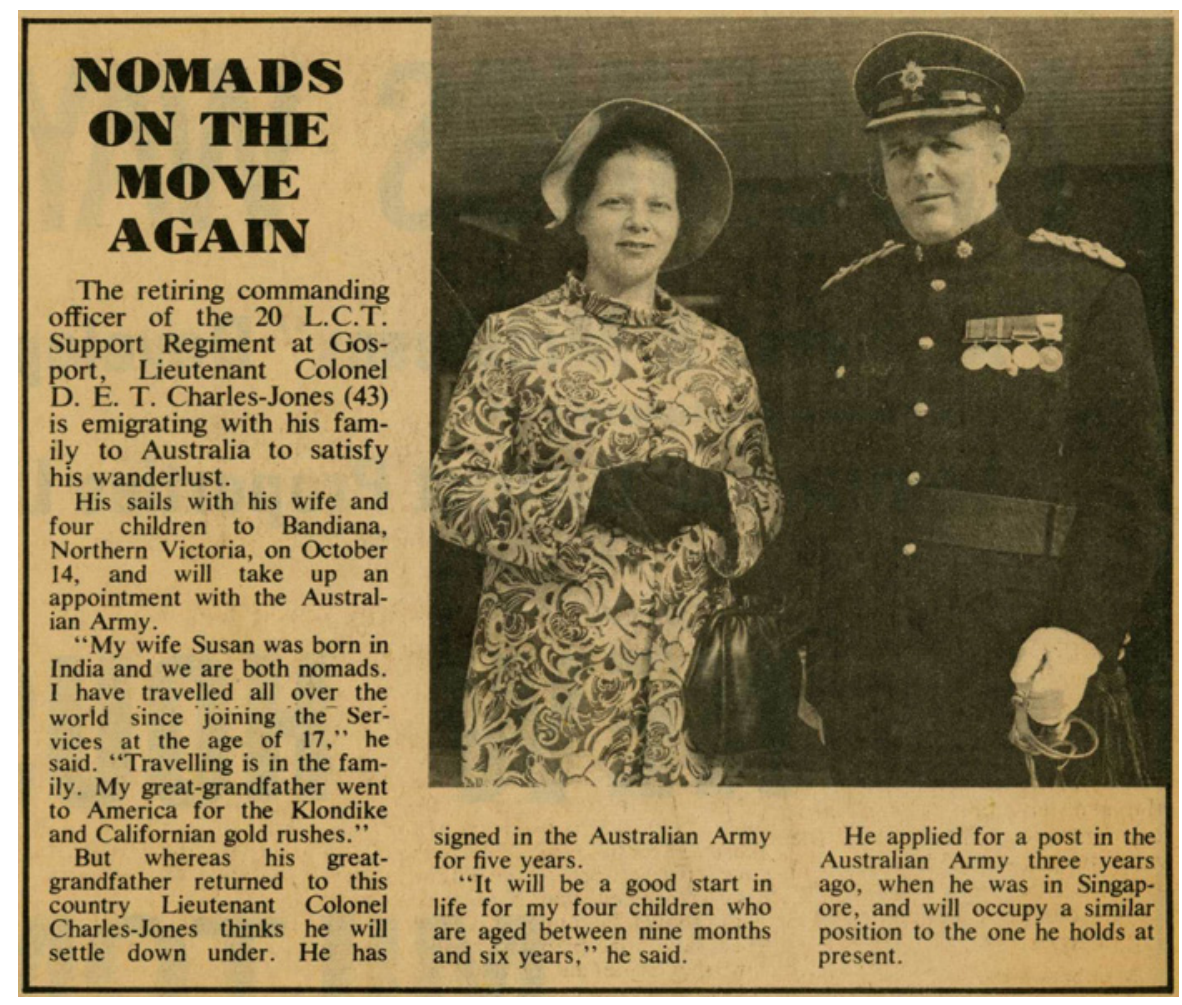

Undated news cutting, Portsmouth, 1970.

There is nothing particularly new about the migrant experience driving life writing. While researching personal histories of the immediate postwar British emigrant generation to Australia - the 'ten-pound Poms' - we routinely encountered ageing grandparents, acutely conscious of the enduring impact of their migration, who had already written an autobiography for the benefit of their families. The son of one of these celebrated the fact that his father's 'great knowledge of the last nearly eighty years will not be lost upon his death. We can read it ourselves and hand it to our children to read and they can hand it to their children.' 6 In more recent years, prompted in some ways by a younger, more middle-class, often tertiary-educated migrant generation, at ease with writing, the urge to narrate the migrant life has taken a rather different form. For Boyle in 2005, it focused on how the major differences between English and Australian landscapes, which initially struck her, were diminishing over time: '[M]aybe the differences are becoming less significant the longer I am here and this landscape means "home" to me. ${ }^{7}$ Such reflections can serve a useful purpose in the continuing project of coming to terms with the meaning of migration in a mobile life that might seem to be in constant flux. Life writing in these cases 
is likely to be undertaken largely as a therapeutic exercise, for the self rather than the family, often to speculate on possible moves still ahead. Caroline Streeter, for example, concluded her long reflections on 30 years of movement between England and Australia with an eye on the future, the certainty that for her and her family the migratory journey was unfinished: 'It seems that our migration story is not over yet, and may take some very interesting twists and turns in the years to come. ${ }^{\prime 8}$ All migrants tend to dwell on the reasons that drove them to leave their homeland in the first place, and the reasons invariably owe something to socioeconomic and political contexts; for young migrants of the 1980s, for example, the resort to the explanatory label 'Thatcher refugees' is remarkably common. ${ }^{9}$ Emotional factors, too, well beyond strictly economic imperatives, have invariably played some part in migrant motivations; in the immediate postwar years, for example, the opportunity to make a 'new start', perhaps to revive a failing marriage, was occasionally remembered as the crucial motivating factor. ${ }^{10}$ As the option of migration became financially easier in the later twentieth century, however, when a decision to relocate across the globe could be made virtually on a whim, such personal stories and explanations have tended to intrude more commonly into autobiography. ${ }^{11}$ These can include the quest for a lifelong romantic fulfilment, reaction against a narrow parochial or dysfunctional family life or the traumatic events and complications of a transnational marriage. Such matters are routinely the stuff of autobiographical writing, but can be complicated when blended with a migration narrative, which, in recollection at least, is likely to emerge as the centre and driving force of the life story. ${ }^{12}$

The migration-centred story in life writing is also common in oral testimony. Informants, especially older migrants, for the book I wrote with Alistair Thomson, Ten Pound Poms, ${ }^{13}$ tended to interpret their life and identity through their 'lens' of migration, the central turning point through which they reflected on their lives before and after the act of migration - an act that coloured evaluation of their life, whether told through stories of family, marriage or career. Informants who had experienced some other life-changing event, such as war service, prisoner-of-war experience, childhood evacuation or the early death of a parent, which might normally be expected to be the critical turning point, shifted priority to migration for their sense of its power to transform their lives. This pivotal transformation was seen most dramatically in terms of domestic, marital and family life. The stories elaborated below illustrate ways in which the self-styled mobile persona, when enmeshed closely with family attachments, can obscure as much about migrant subjectivity as it explains.

Given the conditions of postwar Britain, with the slow pace of reconstruction, shortages and the continuation of rationing until 1954, it should not be surprising to find migrants of the 1940s and 1950s dwelling on their escape from postwar 
austerity to the greater opportunities of Australia, and this is one of the distinguishing features of the migration stories of that generation. Albert Lougher, who emigrated in 1954, had suffered traumatic experiences as a twice-captured prisoner of war in Tobruk and Italy, and spent time in slave-labour conditions near Dachau building Farben's poison gas factory. ${ }^{14}$ He spoke about his feelings on demobilisation, of wishing he was dead, of alienation from what he thought was a re-emerging class-ridden society that had left his father unable to provide for his family, and bitterness about feeling cast adrift. His recovery began when he gained an apprenticeship as a watchmaker and he began to aspire to a more comfortable suburban life together with his new wife, Ann, his 'saviour'. For Albert, however, looking back on his life in retirement in Sydney, his major life transformation came not with this occupational lift, nor even with his beloved saviour wife, but with his migration, which enabled him to live out his belief that in postwar Britain, and then in Australia, he was part of a 'new generation, not like my Dad'. He meant by this his ability to provide for his family in ways his father never could in London, and not being bound to traditional rigid and authoritarian ideas of family and marriage. When asked about the best and most enduring result of his migration, Albert responded with a celebration of his family life:

Well, I think we've given Australia three good kids and five grandchildren...We've been married now 52 years this year. And we've reaped the benefit of family life. Our children are our companions, we're friends... in fact I've got a daughter coming over this afternoon and she'll bring a bottle and we'll have a wine and a laugh. They always brought their friends in. And I think it's from there...that good life comes.

Albert and Ann, like thousands of postwar British migrants, told their story around that time-honoured password of the migrant - opportunity-but more broadly in terms of what we understand as the self-improvement ethos. Although self-improvement in material terms has always been basic to voluntary migration, we associate the twentieth-century self-improvement ethos powerfully with nineteenth-century movements for respectability and education, which drove migration to the Americas and the Antipodes. In this respect, postwar British migrants could be said to have more in common with their nineteenth-century forebears than with those of their more modern successors from the late 1960s. In both periods, self-improvement has carried a moral as well as an economic meaning, and a powerful belief that a respectable working and family life could be fulfilled more easily through emigration to a new land. Its class connotations were embedded in the alluring propaganda that, for example, promised all the suburban trappings of 'the Australian way of life' to struggling skilled and semi-skilled postwar migrants. It was expressed in all those family stories written for grandchildren by our informants, by men such as Leonard Hedges, who 
went along with his wife's drive to emigrate for 'something better' and insisted that 'family comes first', 15 and by women such as Margaret Hill, who, after she left a controlling and violent husband in Adelaide, struggled to get her children back and build a life for them alone in Melbourne, and has now written two books telling the story. ${ }^{16}$ Their realisation of the eagerly prized opportunity usually bequeathed an undivided loyalty to the new country, so that in these stories the migrant's Australian identity, virtually given as a reward for benefits received (as in Albert Lougher's declaration, 'we've given Australia three good kids and five grandchildren'), is straightforward. These are fairly uncomplicated stories, then, viewed through a framework of loyalty to the nation-state.

Significantly, however, it was during the years of this same postwar migrant generation that seeds of change were sown for a new and more complicated transnational outlook. Until the 1980s, the postwar schemes to all the former colonies of white settlement were so open ended that almost anyone could qualify to use them for whatever long or short-term purpose they chose. The notable beneficiaries of this were young single men and women intent on 'adventure' and the two-year or more working holiday. These, of course, were the precursors of today's backpackers, but also migrants with more flexible plans about their future, more prone to itinerancy, to pre-planned return and to open-ended readiness to be influenced by shifting employment opportunities and seeing more of the world; they can appropriately be labelled 'serial migrants'. Cheaper mass air travel from the 1970s was central to this change, as were newer corporate employment practices that encouraged skilled and managerial employees to relocate as expatriates, more or less temporarily, around the world-practices that frequently encouraged those expatriates to become permanent migrants. In these conditions, the old self-improvement ethos faded as a primary motivation for migration across the class spectrum. Work and family ambitions remained central to migration decisions, but this was now much more likely to be combined with notions of adventure, which rapidly became the new catch-all motivation, leading to the modern notion of continuing migration and travel as consumerism rather than the traditional self-improvement ethos. In practical terms, however, modern migrants continued to face all the traditional challenges of managing in a new country. Among the most persistent and vexing of these challenges were those to marriage and family.

An example from a woman who began her travels as a single adventuring sojourner to South Africa and who later re-emigrated to Australia should illustrate some of the challenges. Among the popular postwar choices of migrant destinations for the British, apartheid South Africa rapidly became the most problematic, with racial issues commonly cited among primary reasons for choosing other alternatives. By the 1970s, many British South Africans were reconsidering their settlement decision and either returning to Britain or moving on to third countries, with Australia one of the most popular destinations. 
Initially, this was stimulated for the British by racial issues, including the flight from apartheid and the associated instability; subsequently, it was more often driven by security fears. None of these fears concerned Ros Smith when she emigrated, single, to Cape Town in 1972, in company with a young woman friend. ${ }^{17}$ At this stage, Ros was the classic sojourner emphatically seeking 'adventure' and a good time, with plans to move on to Australia after two years; she had made earlier plans to travel with a South African boyfriend, but when he decided he needed to travel alone instead - and to South America - she resolved to embark on her adventure without him. Despite the fact that she refused to answer his letters, in 1973, several months after he returned to South Africa, they married. Her wedding illustrated her ambiguous status as a migrant wife. 'I knew seven people at my wedding, including my husband,' Ros recalled, 'his parents actually lived in Zambia at the time and they drove down from Zambia to South Africa and, they just had two cars loaded with presents from people I didn't even know, I've never met them.'

The isolated English wife's marriage to a South African journalist known for his opposition to the apartheid regime made for a testing social life, and much of Ros's story of this time struggles to express her distress at her isolation and sense of insecurity. 'We would have dinner parties...in South Africa...they used to get very heated and there was table-thumping and I would usually end up in the kitchen sobbing over the dishes.' This was compounded by security fears and the ever-present threat that her husband, Chris, like some of his left-leaning colleagues on the Rand Daily Mail, might be incarcerated by the government; after the birth of her son, Ros feared that if she was to stay in South Africa he would be conscripted into the army to do the regime's dirty work. Political matters thus intruded into family life, and Ros, the migrant wife with few sources of emotional support, recalls a sense of powerlessness and alienation. In response, she struggled to find sympathetic friends and a place in what seemed to be a hostile and threatening society. It took years, first in Cape Town, later in Johannesburg, for her to create a close network of women friends to balance her relative powerlessness. While feeling no religious commitment, she joined the Methodist Church:

I wasn't religious in England...but then in South Africa I joined the Methodist Church...I went to all sorts of Bible readings, I became friends with my minister and his wife, they came for dinner with us...all the time, I just needed support...I needed a...crutch, I couldn't deal with it. The politics were too big for me.

Ros also had to negotiate her recurrent homesickness, which threatened her marriage with Chris, her South African husband, who was quite unable to understand his wife's emotions, but with a surprise revelation in store for him when they ultimately moved on to Melbourne in 1982: 
[I]t wasn't until we came here that Chris understood how $I$ felt. Chris is, was, never tolerant of homesickness because he thinks my home is wherever he is. Which is not true...you're not home-homesickness is a very strange thing...it's not for people, and it's not for place, it's for a real mixture and it's for emotions, it's for smells, it's for familiarity, it's just a whole network of things we miss.

Ros's reflections on how things changed when they fled South Africa and migrated to Australia provide some insight into her condition as a migrant wife in South Africa, in contrast with the advantage she enjoyed during their brief period in England, and the more equal footing she shared with Chris in Melbourne, when both of them carried a migrant identity.

Well, one of the good things...for me, a personal thing, is that [Australia] was neither of our homes. Okay, when I went to South Africa it was Chris's home, and his friends, and they became my friends, I have no quarrel with that, but somehow, because he is a very dominating person I find here, okay we're [on a] level playing field...Yes, it's up to both of us now.

Recalling that when they had resolved to leave South Africa they canvassed several alternative destinations, especially Canada, and return to England, Ros described Chris's aversion to the English weather, how she deferred to him on that issue, but then reflected on how her identity as a woman had evolved along with her migrant identity and personal growth.

So the reason not to go back to England was the weather, he hated the weather...I was torn, I think is probably the honest answer, but I had to consider him. Chris is not easy to live with if he isn't happy, and I have had years of him being unhappy politically and I thought if I got him somewhere where he's happy he'll be easier to live with...I can say that now because I've come to terms with all of this now, if you'd asked me ten years ago I don't know that I could have answered that, because now I've reached a stage in my life, I'm nearly 60, and if Chris is unhappy and it's not me causing the unhappiness, it's his problem and he must sort it out, I'll help him, but I don't take it on any more as my problem. Whereas I was taking England's weather and being responsible for it making him unhappy, that's what would happen. I've moved, I've grown...I still value my marriage very much but women nowadays are much stronger, as I'm sure you know, and I am an independent woman now and I'll do things and discuss things with Chris and I would never deliberately upset him but if he doesn't like it, like he doesn't like me going back to England without him to see my mother, well he's revolting before I go, he sulks when I get back, I still go, whereas I wouldn't have done in those days. 
Ros's narration of her life history here is certainly driven by her lens of migration; it recurs when she recounts persistently what a success the move to Melbourne became for Chris, herself and her children. It is magnified each time she embarks on her nearly annual family visits to England, and occasionally to South Africa - an experience that sets her generation far apart from that of the early postwar years, and keeps alive her subjective perception of herself as routinely mobile. Ros is, however, conscious here too of a different kind of journey in her reference to her growth as a person, a woman and a wife as well as a migrant. 'I've moved, I've grown' is a powerful motif of personal and literal movement. Ultimately, while Ros is conscious of her migrant identity, it remains unresolved, and perhaps unresolvable, whether her personal journey towards greater confidence and autonomy has been more central to her than her geographical mobility and Australian attachment. Her story underlines the complex, and not necessarily simply causative, relationship between migration and personal change.

On first contact with us, Ros described herself as a 'research project waiting to be discovered', hinting at the importance she attached to her magpie-like accumulation of documents from her migrant past and trying to make sense of her life history. For Ros, as for others, this has translated into the writing of a detailed migration-centred autobiography. Another woman who sent us her initial 50-page draft - apologising: 'I've worried at times that it's too much like a soap opera' - wrote at length about her marriage in England to an Australian and the steep learning curve she experienced on the ship voyage to Australia in the late 1960s when, quite suddenly, she saw a new, and unwelcome, side of her husband. She shared the experience with a woman in a similar situation: 'Our stories have many parallels; we had married men we didn't really know, who could keep up a pretence away from home and we were both very naive about the decision to emigrate. ${ }^{18}$ The parallels here with earlier war-bride experiences are striking: a reminder that among the huge changes in Western migration between the 1950s and 1990s, there remains an interplay of change and continuity. Among the continuities, the strongest is a preoccupation with the influence of migration on marriage and family and, conversely, the power of marriage and family to shape migration.

The ubiquitous family emphasis can be seen in a wide variety of migration experiences. Maurice Bassindale, like Ros Smith, was a serial migrant and, like her, his marital and family history was bound up deeply with his migration, but his mobile trajectory could not have been more different. ${ }^{19}$ Maurice, who began working life in 1956 in his native Lincolnshire as a trained motor mechanic, soon graduated to the management of the maintenance and operation of large vehicle fleets and seemed set for a successful career at home. By 1960, he was married with two children and had a prosperous future ahead, although most of his work involved frequent travel around Britain, so he was often away from home. By 
1977, after several moves, buying and selling houses, and with the children in private schools, life was comfortable but constrained by mortgage debts, and the offer of twice the salary for a contract position in Saudi Arabia seemed to Maurice an opportunity too good to refuse. After earnest family conferences, Maurice left for Riyadh, alone, and his wife, Maureen, joined him in 1980. The strain of separation and expatriate compound living, however, took its toll, and Maureen returned to England in 1982, and the couple divorced in 1984. By then, Maurice had transferred to Houston, Texas, in 1983, with the same employer.

Throughout this period, Maurice never considered himself to be a migrant, rather simply a transient worker temporarily away from home. From the 1950s, the temporary employment of British skilled workers such as Maurice in developing countries, especially those of the Middle East such as Saudi Arabia, opened up new possibilities for continuing mobility among a much wider cross-section of British society. In effect, this promised the democratisation of the expatriate experience well beyond the upper and middle-class foot soldiers of the old empire, bringing the abbreviated 'expat' label into much more common currency. For many, it was defined by living in compounds and sharp separation from the local community, and this is largely what Maurice experienced in Saudi Arabia. He remembered his single quarters and conditions:

We all each had a room in...like a guest-house and with a communal dining room, you had your own bathroom toilet facilities, no social life really...you got up in the morning and went to work... We didn't have a swimming pool, or anything like that, so we had virtually no recreation at all.

When Maurice transferred to Houston in 1983, the compound living ceased and he experienced something of American life, but he continued to regard himself as an expatriate, with frequent visits back to Britain. During those visits, he formed a new relationship, with an English woman, who eventually joined him in Houston, and when the company offered a further transfer to Sydney, Maurice took it up with enthusiasm, she joined him, and they married in Sydney in 1986. The second marriage was, however, unstable, and Maurice's regular work travel around Australia meant that although they enjoyed numerous world holidays together there was little home life to nurture the relationship, and in 2001 they divorced. As Maurice remembers it, he also came to miss what he had enjoyed of his family life with his first wife.

I did miss the family life that Maureen and I had had... And bearing in mind that Maureen and I, we knew each other two or three years before we married and then we...were married for 26 years, and when you've...been that close to someone for that long, you do miss a lot of little intimate things about your partner. 
While his second marriage was fragile, it did, in the early years, exercise for Maurice a critical influence on his identity. Soon after marrying his second wife, Maurice's company offered him yet another transfer back to Saudi Arabia, initially, at least, alone on what was called 'bachelor status'. Not willing to leave his new wife, he declined, and with other plentiful Australian job offers to consider and an application for Australian permanent residency nearing approval, he left his employer and soon obtained other attractive work. In Maurice's narrative, this was the crucial moment when he moved from being an impermanent expatriate to a settled migrant, under the impetus of marriage in the new country, an interest in citizenship and a sense he had begun to feel since arrival that Australia was a country he could call home.

I settled in Australia by choice...I felt very comfortable there...I remember the day I arrived from...Houston and we were collected at the airport and driven into...North Sydney where I was staying, and...immediately I felt very comfortable, I felt as though: 'This is like home'. It was very green, and little shops, rather than the big...shopping malls that I'd got used to in Houston, and none of the concrete and glass that existed in Houston. And...the longer I stayed the more I felt this was home. I enjoyed the...warmth and...the sort of semi-outdoor life.

The settled migrant, however, remained highly mobile, with regular trips back to England, where he maintained close contact with his two adult children. Family and mobility again changed Maurice's story. His daughter, Susan, had, he thought, inherited his own penchant for travel and adventure, and developed a promising career working in cruise ship casinos; she eventually married a business partner and they managed the casinos together, regularly travelling around the world. By 1987, they had decided to settle on shore, in Vancouver, where their first child was born. In 2001, they moved to Victoria, British Columbia, and since Maurice had recently retired he offered to help with the move. After a return visit to Sydney and an offer from Susan to stay with them, the move ultimately changed to permanent settlement in Canada. More changes, however, lay ahead. His first wife, like Maurice in the throes of ending a second marriage in England, made a visit coinciding with Maurice's in Victoria, they renewed regular contact after many years being out of touch and, by 2002, Maureen had emigrated to Victoria, where they again lived together. As Maurice wrote, this was 'a very large bonus': Maureen was now 'enjoying being with me and close to our daughter and her family. We hope to live happily ever after! Is that a happy ending or what!?'

As is common, however, a mobile past leads to an open-ended and potentially unfinished mobile future. At the time of the interview, Maurice had been living in Canada for only three years, and while he was gradually coming to feel settled he still missed many aspects of Australia, where he had assumed he would settle 
permanently. After reading the transcript of our interview, he wrote an addendum to stress his continuing attachment.

I feel very patriotic towards Australia, returning as frequently as possible, and would live there permanently if my family were prepared to relocate there. Some of my best friends are Australians and we keep in touch regularly by e-mail and occasional phone calls. I certainly miss them and am always pleased to hear from them. ${ }^{20}$

As his crucial qualifier insists, however, he is happy for family to dictate the future. A similar response governed his attitude to living in Britain, where there was little doubt about his priorities: 'I go back to Britain, and I don't particularly want to go back and live in Britain, but...I wouldn't say never, but if the family were there I'd go tomorrow... I don't see anything wrong with Britain.' So while Maurice has come to take a mobile persona for granted, he is content for its direction to be shaped by family dynamics, which have progressively loomed larger in his own narration of his life story. Ultimately, the intense geographical mobility that has sculpted his identity has been eclipsed by his primary role as a family man, albeit a man whose later migrations have been driven by the migrations of his own family. In his autobiographical reflections, he is emphatic that his first national loyalty belongs to Australia, but it is a contingent loyalty that ultimately gives way to the transnational ties of family.

In their different ways, the stories told by Ros Smith and Maurice Bassindale provide vivid illustrations of the power of the lens of migration to shape autobiographical narratives. In the past generation, this has come to be defined increasingly by the migrant's perception of the self as a well-travelled mobile personality. One of the stimulants of change in the late twentieth century was the shift from a colonial to a global context for migration in the British world, and these migrants illustrated that shift in their internalisation of a sense of themselves as inherently mobile personalities, more or less settled in one country while not exclusively tied to any; it was symbolised by some migrants' declarations that they wished to have their ashes scattered in more than one country, when the bonds of family finally loosened. ${ }^{21}$ At the same time, however, in their family centredness, these transients continue to shape their lives and tell their stories in deeply traditional ways, albeit with varying notions of family and contrasting experiences that might be explained, as with Ros and Maurice, by gender difference. Both carry an awareness of the powerful ways in which mobility has shaped their sense of identity, but both of them also place equal weight on dynamics such as family attachment and personal growth in telling their life stories. Their narratives therefore struggle to balance shifts in personal family belonging with a world that allows geographical mobility on an unprecedented scale. These migration stories might point the way to closer understanding of the effects of intense global mobility. Modern migration has 
affected the most intimate details of migrant lives and created a dizzying web of transnational ties, and now it has gradually come to redefine how people see themselves. At the same time, the traditional bonds of family have continued to drive the course of migration and to shape the identities people construct when they strive to make sense of their past.

\section{Notes}

1 The project draws on migrant testimony in written and oral history form from more than 180 British migrants - 123 interviewed - mainly to Australia, Canada and New Zealand, including returnees and 'serial migrants' to more than one country. A monograph, tentatively titled The Modern British Diaspora, is scheduled for publication in 2010.

2 On the postwar British migrant generation to Australia, see Hammerton, A. James and Thomson, Alistair 2005, Ten Pound Poms: Australia's invisible migrants, Manchester University Press, Manchester.

${ }^{3}$ For the most recent exploration of the extensive British diaspora, describing it in 2006 as the world's third largest (p. viii), see Sriskandarajah, Dhananjayan and Drew, Catherine 2006, Brits Abroad: Mapping the scale and nature of British emigration, Institute for Public Policy Research, London.

4 Self-improvement can be shown to motivate virtually all migrations of austerity or of rising expectations, but I refer here to the more explicit movement, setting in from the early nineteenth century, associated with the striving of workers for not just economic welfare but for respectability and intellectual and social improvement, at home by, for example, joining mechanics' institutes and friendly societies and participating in chapel activities, and abroad through emigration. A similar drive for migrants' respectability in the postwar years linked advanced economic conditions with opportunities for improved educational prospects for children. See Harrison, J. F. C. 1961, Learning and Living, 1790-1960: A study in the history of the English adult education movement, Routledge and Kegan Paul, London.

${ }^{5}$ Correspondence, Kate Boyle to A. J. Hammerton, 26 June 2005, and Written account, La Trobe University Archive in British Migration (hereafter LU), DB50. Alistair Thomson's use of women migrants' letters alongside interview testimony in Chapter 9 of this volume offers a variation on the same theme.

6 Baines, John Edward n.d. [c. 1998], Life Wasn't Meant to be Easy, Bet Saleter and Eileen McKechnie, Geelong, Victoria.

7 Kate Boyle, Written account, June 2005, LU DB50.

8 Caroline Streeter, Written account, February 2006, LU DS120.

9 For example, Viviane King, Interview, Sydney, 23 March 2007, LU DK20.

${ }^{10}$ For example, Joanna White, Interview, South Melbourne, Victoria, 24 June 1998, LU 0991; Hammerton and Thomson, Ten Pound Poms, p. 80.

11 Financial capacity is of course highly variable, but relates here to the tendency for British migration since about the 1970s to take on a more middle-class profile statistically; see Sriskandarajah and Drew, Brits Abroad, pp. 22-5.

12 Collections of contemporary migrant letters can serve a similar function, illustrated by Alistair Thomson's use of postwar women migrants' letters alongside their interview testimony in Chapter 9 of this volume.

13 Hammerton and Thomson, Ten Pound Poms, pp. 17-18, 62.

14 Albert and Anne Lougher, Interview, Balgowlah, New South Wales, 22 June 1999, LU 0544;

Hammerton and Thomson, Ten Pound Poms, pp. 57-62.

15 Leonard Hedges, Interview, Claremont, Tasmania, 25 September 1999, LU 0410.

16 Margaret Hill, Interview, Chelsea, Victoria, 11 September 1998, LU 0423; Hill, Margaret 1999, Corrugated Castles, Cromwell, Melbourne, and 2003, Water Under the Bridge, published privately; Hammerton and Thomson, Ten Pound Poms, pp. 78-9, 234-6.

17 Ros Smith, Interview, Melbourne, 28 October 2005, LU DS50.

18 Amanda Stuart, Written account, March 2006, LU DS125

19 Maurice Bassindale, Interview, Victoria, British Columbia, Canada, 13 April 2006, LU DB35.

20 Maurice Bassindale, Addendum to transcript, 28 July 2006, LU DB35.

21 See Susan Charles-Jones, Interview, Yackandandah, Victoria, May 2005, LU DC30. 